\title{
PENGARUH HUBUNGAN PEMBELAJARAN DARING DI ERA PANDEMI COVID-19 TERHADAP MENTAL PESERTA DIDIK
}

\author{
Elen Asti \\ Fakultas Ilmu Pendidikan, Universitas Negeri Yogyakarta \\ e-mail : elenasti.2020@student.uny.ac.id
}

\begin{abstract}
Abstrak
Menjalani pembelajaran dalam moda daring di tengah era pandemi Covid-19 bukanlah suatu hal yang bisa dikatakan mudah, terlebih terkait dengan kesehatan mental peserta didik dalam menjalani pembelajaran tersebut. Hal itu akhirnya menyebabkan tekanan psikologis yang akhirnya berisiko mengganggu kesehatan mental terhadap peserta didik terutama dalam menjalani pembelajaran daring di masa pandemi Covid-19. Tujuan penulisan ini yaitu memaparkan pengaruh apa saja serta relevansi terkait hubungan pembelajaran daring di masa pandemi terhadap kesehatan mental peserta didik, agar menjadi urgensi yang penting untuk dikaji sehingga baik pendidik maupun peserta didik bisa saling memotivasi terhadap kesehatan mental selama pembelajaran daring era pandemi tetap terjaga dengan baik. Metode yang digunakan dalam penulisan artikel ini adalah penelitian studi literatur dengan pendekatan penelitian deskriptif kualitatif. Hasil penelitian menunjukkan bahwa, jika dilihat dari sisi praktisnya, pembelajaran daring memang efektif di tengah pandemi, namun tidak untuk psikologis dan mental peserta didik. Untuk itu, dalam memecahkan masalah tersebut perlu adanya analisis terhadap faktor lain yang mempengaruhi kesehatan mental peserta didik selain pembelajaran daring. Sehingga, menjadi bahan pertimbangan untuk menemukan solusi yang tepat dalam menjaga serta meningkatkan kesehatan mental peserta didik saat menjalankan pembelajaran daring.
\end{abstract}

Kata Kunci: pengaruh, pembelajaran daring, kesehatan mental

\section{THE EFFECT OF ONLINE LEARNING RELATIONSHIPS IN THE ERA OF THE COVID-19 PANDEMIC ON STUDENTS' MENTAL}

\begin{abstract}
Undertaking learning in online mode in the midst of the Covid-19 pandemic era is not something that can be said to be easy, especially related to the mental health of students in undergoing the learning. This eventually causes psychological pressure which ultimately risks disrupting the mental health of students, especially in undergoing online learning during the Covid-19 pandemic. The purpose of this paper is to explain what effects and relevance are related to the relationship of online learning during the pandemic to the mental health of students, so that it becomes an important urgency to be studied so that both educators and students can motivate each other towards mental health while online learning in the pandemic era is maintained properly. good. The method used in writing this article is a literature study research with a qualitative descriptive research approach. The results show that, from a practical point of view, online learning is indeed effective in the midst of a pandemic, but not psychologically and mentally for students. For this reason, in solving these problems it is necessary to analyze other factors that affect the mental health of students besides online learning. Thus, it becomes a consideration to find the right solution in maintaining and improving the mental health of students when carrying out online learning.
\end{abstract}

Keywords: influence, online learning, mental health.

\section{PENDAHULUAN}

Wabah virus Covid-19 tidak disangka menjadi suatu momentum dan dampak yang ditimbulkan dari adanya virus ini dirasa cukup besar, tidak hanya di Indonesia saja, melainkan hampir di seluruh dunia. Wabah Covid-19 muncul pertama kali pada bulan Desember
2019 di Wuhan, Provinsi Hubei, Cina (Efendi : 2020). Penyebaran virus Covid-19 yang sangat cepat ini, terjadi hanya dengan melalui interaksi dalam aktivitas sehari-hari, bahkan terdapat beberapa yang terinfeksi tanpa disertai gejala apapun. 
(Perencanaan et al., 2020) Data global per 2 Juni 2020 menunjukkan bahwa terdapat 6.140.934 orang dari 216 negara di dunia terkonfirmasi wabah Covid-19 dan 373.548 orang diantaranya meninggal dunia. Data Indonesia menunjukkan ada 27.549 orang yang tersebar di 34 provinsi positif Covid-19 dan 1.663 orang diantaranya meninggal dunia.

Bisa dirasakan bahwa dampak yang terjadi begitu besar atas timbulnya wabah Virus Covid-19, salah satunya yakni dalam bidang pendidikan. Melalui keputusan Kementerian Pendidikan dan Kebudayaan, pemerintah telah menetapkan aturan bagi seluruh perguruan tinggi, layanan pendidikan tinggi, dan sekolah untuk menyelenggarakan pembelajaran secara daring, dengan tujuan guna mencegah penularan virus Covid-19 yang masih sangat tinggi.

(Fitriyani et al., 2020) Pembelajaran secara daring dianggap menjadi solusi yang baik dan efektif dalam melaksanakan program pembelajaran. Tetapi, ternyata permasalahan lain timbul dalam proses pembelajaran yang dilakukan, terdapat banyak kendala yang dihadapi mulai dari jaringan yang tidak stabil, kuota yang digunakan cukup banyak, belum lagi yang bertempat tinggal di daerah pedesaan dan kesulitan untuk mencari sinyal di dalam mengikuti pembelajaran secara daring (Basar, 2021).

Dari individu-individu tersebut tentu perlu beradaptasi terlebih dahulu dengan situasi yang sedang terjadi ini, bukan hanya dari segi fisik namun juga dari sisi segi kesehatan mental perlu turut diperhatikan. (Ardhani \& Syalsabhila, 2020) Tidak sedikit dari peserta didik merasa bahwa dirinya tidak sanggup mengikuti pembelajaran secara daring dan merasa tertekan terhadap pemberian tugas yang tidak sedikit. Di samping itu, faktor kesenjangan ekonomi juga menjadi salah satu dampak yang dirasakan dari adanya pandemi, karena tidak memiliki dana untuk membeli tools atau paket data internet guna mendukung pembelajaran daring (Ardhani \& Syalsabhila, 2020).

Hambatan lainnya yang dirasakan adalah pembelajaran daring cenderung lebih melelahkan dan membosankan karena peserta didik tidak dapat berinteraksi secara langsung baik dengan pengajar dan teman-temannya, hal itulah yang juga menjadi salah satu faktor yang turut menjadi hambatan selama pembelajaran daring yang akhirnya mengakibatkan frustasi bagi peserta didik, dan apabila terus menerus berlanjut akan menimbulkan ketergangguan pada kondisi kesehatan mental mereka (Moh Muslim, 2020).

Dari beberapa hambatan-hambatan yang dirasakan oleh peserta didik tersebut, justru dikhawatirkan akan menjadi berita baru yang menyatakan bahwa kasus yang terjadi saat ini, tidak lagi tentang banyaknya berapa jumlah korban yang terpapar virus Covid-19 melainkan muncul permasalahan lain terkait dengan kondisi kesehatan mental peserta didik selama pembelajaran daring ini.

(Lindasari et al., 2021) Peserta didik banyak yang depresi dan stress, karena ketidakjelasan sistem pembelajaran secara daring. Menurut (Montgomery, 2011) Depresi didefinisikan sebagai suatu keadaan yang akan mempengaruhi individu tersebut baik secara afektif, fisiologis, kognitif maupun perilakunya, sehingga hal itu mampu mengubah pola serta respon yang biasa dilakukan. Gejala terhadap seseorang yang depresi akan melakukan hal-hal diluar kendalinya, hingga menyebabkan individu tersebut secara tanpa sadar untuk mencoba bunuh diri (Hadi et al., 2017). Hal tersebut diakibatkan dari depresi maupun frustasi karena banyak tekanan dan tidak adanya kemampuan untuk self control terhadap seseorang itu sendiri (Putri \& Sugiasih, 2020). Permasalahan ini bukanlah hal yang bisa dikatakan sepele, terlebih dalam konteks ranah pendidikan.

Menghadapi pembelajaran secara daring tentu menjadi tantangan baru dalam dunia pendidikan terutama di Indonesia. Untuk mewujudkan tujuan pembelajaran yang diharapkan, oleh sebab itu, sebagai pendidik tentu memiliki peran yang sangat signifikan dalam memberikan motivasi dan dorongan kepada peserta didiknya untuk membangkitkan minat belajar peserta didik terlebih pada masa daring ini (Hasfira \& Marelda, 2021), dan bagi peserta didik juga harus menumbuhkan pemikiran positif dalam diri mereka sendiri agar kesehatan dari segi fisik maupun mental mereka bisa terjaga dengan baik.

Terkait kesehatan mental tidak bisa dianggap remeh dan tabu begitu saja, hal ini perlu untuk dikaji dan diulas karena dikhawatirkan akan semakin banyak dan meluasnya kasus serupa yang terjadi apabila 
tidak diatasi dan diupayakan untuk mencari solusi yang tepat.

Tujuan penulisan ini adalah untuk mengetahui faktor lain apa saja yang dirasakan oleh peserta didik dalam pembelajaran daring dan relevansinya terhadap kesehatan mental agar menjadi suatu upaya untuk menemukan solusi yang tepat dalam pemecahan masalah ini. Penulisan ini akan membahas mengenai faktor-faktor yang menjadi hambatan apa saja yang dirasakan oleh peserta didik selama pembelajaran melalui moda daring, kemudian keterkaitan antara kesehatan mental yang didasarkan pada hambatan tersebut dengan pembelajaran daring. Apakah sepenuhnya memang karena pembelajaran daring?. Bagaimana solusi terbaik yang bisa dilakukan nantinya?. Sehingga dengan demikian, pentingnya kesehatan mental maupun psikis, terlebih dalam situasi pandemi seperti ini agar turut menjadi kesadaran bagi setiap individu bahwa sangat penting untuk diutamakan selain kesehatan secara fisik.

\section{METODE}

Pada artikel ini menggunakan metode studi literatur dengan menggunakan pendekatan deskriptif kualitatif. Metode pengumpulan data adalah studi pustaka. Menurut (Zed, 2014) Pada riset pustaka (library research), penelusuran pustaka tidak hanya untuk langkah awal menyiapkan kerangka penelitian (research design) akan tetapi sekaligus memanfaatkan sumbersumber perpustakaan untuk memperoleh data penelitian. Adapun sumber data yang digunakan bersumber dari jurnal, artikel dan sumber pustaka yang relevan dengan pembelajaran daring terhadap kondisi kesehatan mental. Dari data yang diperoleh kemudian dikompilasi, setelah itu data perlu dianalis dan kemudian disimpulkan.

Kompilasi data merupakan proses dalam menyusun data kedalam urutan-urutan tertentu sehingga menghasilkan database data yang runtut dan lengkap (Sidig, 2015). (Hardani et al., 2015) Kegiatan analisis data ditujukan untuk mengetahui makna, kedudukan dan hubungan antara berbagai konsep, kebijakan, program, kegiatan, peristiwa yang ada atau yang terjadi, untuk selanjutnya mengetahui manfaat, hasil atau dampak dari hal-hal tersebut. (Sidig, 2015) Penarikan kesimpulan diartikan sebagai proses membuat kesimpulan dari keseluruhan studi yang telah dilaksanakan.

\section{HASIL DAN PEMBAHASAN \\ Hasil}

Pandemi Covid-19 menjadi suatu wabah yang cukup besar dampaknya salah satunya yakni dalam bidang pendidikan. Guna mengurangi penularan virus Covid-19 pemerintah Kementerian Pendidikan dan Kebudayaan lantas mengeluarkan keputusan untuk melakukan pembelajaran secara daring yang dianggap cukup efektif. Menurut (Lestari \& Magdalena, 2021) mengatakan bahwa jika dari dilihat dari sisi praktisnya pembelajaran daring memang cukup efektif dan efisien namun tidak bagi kondisi kesehatan mental serta psikis peserta didik yang cenderung lebih memburuk dari sebelum adanya wabah pandemi Covid-19.

(Browning et al., 2021) Peserta didik merasa seperti merasa terjebak dalam isolasi karena kurangnya sosialisasi sehingga membuat mereka semakin tertekan karena hanya interaksi komunikasi satu arah melalui virtual.

Emosi yang tidak stabil membuat peserta didik menjadi seorang yang tempramental akibat dari kurangnya interaksi serta sosialisasi dengan teman sebayanya karena tidak bisa bertatap muka satu dengan lainnya (Wijaya, 2021).

Tabel 1: Perasaan anak saat menjalani kegiatan pembelajaran

\begin{tabular}{cc}
\multicolumn{2}{c}{ daring } \\
\hline Tingkat Kesenangan Siswa & Persentase \\
\hline Tidak senang & $76,7 \%$ \\
Senang & $23,3 \%$ \\
\hline
\end{tabular}

(Sumber : koran tempo KPAI survei 13-20 April 2020. Jumlah koresponden 1700)

\section{Pembahasan}

Dari hasil survei penelitian yang telah dilakukan oleh KPAI tersebut, hal tersebut menunjukkan bahwa sebagian besar atau sekitar hampir $76,7 \%$ peserta didik merasa tidak senang terhadap pembelajaran daring. Jika disimpulkan, itu berarti bahwa pada akhirnya dari ketidaksenangan tersebut lantas memicu emosi yang tidak stabil dan hingga 
akhirnya memicu stress dan depresi lantaran melakukan suatu hal yang pada dasarnya tidak disukai dan hal itu terjadi hampir selama satu tahun ini.

$$
\text { Sisanya sebanyak 23,3\% }
$$

mengungkapkan bahwa senang terhadap pembelajaran daring, hal ini karena sebagian persen tersebut menganggap pembelajaran daring memang cukup efektif serta efisien. Namun pada kenyataannya, sangatlah terlihat masih banyak siswa yang merasa tidak senang dan sangat mengeluhkan hal tersebut. Hal ini sangatlah memprihatinkan terhadap kondisi kesehatan mental peserta didik terlebih dalam situasi pandemi Covid-19. Kondisi kesehatan mental menjadi peran yang cukup siginifikan disamping kondisi kesehatan fisik.

Dari kedua hal tersebut memiliki porsi dan peran masing-masing yang cukup signifikan dalam penunjang untuk melakukan aktivitas sehari-hari. Apabila kondisi mental tidak baik, tentu akan mengganggu peserta didik khusunya dalam mencapai tujuan dan hasil belajar dan pembelajaran nantinya.

(Badaruddin et al., 2016) Kondisi kesehatan mental yang kurang baik, tidak akan memicu serta mendorong tumbuhnya motivasi dalam diri seseorang, sehingga apabila dorongan motivasi tidak timbul, hal tersebut tentu akan berpengaruh pada tingkat kefokusan peserta didik pada pembelajaran yang dilakukan dan menjadikan hasil belajarnya kurang optimal. Terlebih pembelajaran secara online atau daring ini yang menuntut peserta didik untuk disiplin dan membutuhkan kemandirian dalam belajarnya. Maka dari itu, perlu adanya saling keterbukaan antara peserta didik dengan pengajar maupun antar teman dan juga peran keluarga untuk saling terbuka dan saling menjaga interaksi komunikasi dengan anak (Setyawan, 2020).

Sebagai makhluk sosial tentu kita juga sangat memerlukan peran dan dorongan motivasi ekstrinsik untuk memberikan arahan dan masukan guna menjaga kondisi kesehatan mental dan mood dengan baik. Faktor lingkungan juga menjadi salah satu faktor ekstrinsik yang bisa menumbuhkan motivasi dalam diri seseorang untuk meningkatkan minat belajarnya (Journal, 2017). Lingkungan belajar yang kondusif tentu akan berpengaruh bagi seseorang untuk dapat mengurangi timbulnya suatu perasaan kecemasan yang ada pada diri individu tersebut (Suardana \& Simarmata, 2013). Sehingga dengan kondisi yang seperti itu diharapkan mampu membuat kondisi mental seseorang tidak semakin tertekan.

(Indasari et al., 2020) Reaksi yang akan timbul apabila kondisi sosial emosi tidak terkontrol dengan baik sangat beragam mulai dari rasa cemas, takut, marah, kecewa, sedih terus menerus dan menjadi semakin tertutup terhadap sekitar, putus asa yang hingga akhirnya timbul mati rasa dalam diri peserta didik dan dikhawatirkan mereka tidak memiliki semangat untuk menjalani kehidupan karena merasa tidak mampu untuk melakukannya.

Faktor lain dalam penyebab hal yang memicu kondisi kecemasan kondisi kesehatan mental peserta didik yakni banyaknya tugas yang memberatkan dan tanpa adanya bimbingan serta arahan dari guru ataupun pendidik, hal ini sangat bepengaruh lantaran peserta didik merasa khawatir dengan nilai akhir yang akan mereka peroleh. Mereka tentu akan terus memikirkan bahwa mampukah hasil yang didapat akan maksimal sesuai dengan target capaian serta tujuan yang hendak dicapai sudah optimal (Christianto et al., 2021).

Situasi pandemi ini tidak diketahui akan berakhir kapan dan tentu pendidikan serta pembelajaran harus tetap berlanjut. Langkah dalam pengelolaan kondisi mental tersebut yakni dari pendidik perlu setiap saat mengontrol dan memberikan arahan dan perhatian yang lebih terhadap peserta didik (Nugraheny, 2020). Sehingga dengan demikian, peserta didik akan merasa bahwa dirinya memiliki support system selain dirinya sendiri dan keluarganya, tidak jarang bahwa terkadang ada banyak dari peserta didik terlebih bagi mereka yang broken home merasa bahwa tidak ada support system di sekitarnya, dan sebagai pendidik selain menjadi pengajar dan pendidik diharapkan 
juga dapat menjadi motivator bagi mereka. Dari sisi peserta didik sendiri juga perlu untuk menerima kondisi maupun keadaan yang sedang terjadi bahwa kondisi sedang dalam masa pandemi Covid-19 dan memang dituntut untuk menerima keadaan yang sedang terjadi ini, selain itu juga perlu untuk mengurangi rasa kecemasan yang berlebihan, disamping itu individu juga memerlukan meditasi untuk menenangkan pikirannya supaya lebih rileks dan tenang (Deliviana et al., 2021).

Maka dari itu kesehatan mental perlu diperhatikan untuk kedepannya, agar pengaruh pembelajaran daring terhadap kondisi kesehatan mental tidak semakin parah dan lebih memprihatinkan.

\section{PENUTUP}

Pembelajaran daring menuntut skills dalam penguasaan IT dan juga tools yang perlu dimiliki untuk menunjang pembelajaran daring. Disamping itu, juga menuntut segala pihak untuk mandiri terhadap pembelajaran yang sedang dilakukan baik dari pendidik itu sendiri maupun peserta didik. Namun, saat kondisi pandemi yang tidak diketahui akan berakhir entah kapan ini, diharapkan baik dari pendidik maupun peserta didik saling terbuka dan melakukan sharing diantara keduanya tersebut. Pendidik juga perlu menimbang tugas mana yang perlu untuk dikerjakan dan mana yang cukup untuk dikurangi. Selain itu pendidik memerlukan strategi dan metode yang mampu membangkitkan proses pembelajaran yang aktif, namun tetap efektif, efisien dan tentunya berdaya guna sehingga peserta didik merasa dirinya nyaman untuk mengikuti pembelajaran.

Bagi peserta didik juga perlu adanya penerimaan baik dari segi kondisi dan keadaan yang terjadi yakni memang sedang tidak memungkinkan untuk dilakukan pembelajaran secara tatap muka, dan peserta didik sendiri perlu memahami bahwa dirinya adalah seorang pelajar yang dimana memang sudah menjadi kewajiban bagi dirinya sebagai pelajar untuk mengerjakan tanggung jawab terhadap tugasnya. Namun, jika memang terbebani karena tugas yang diberikan cukup banyak, mungkin hal tersebut bisa didiskusikan kepada pendidik ataupun pengajarnya supaya bersama-sama dicari solusi terbaiknya seperti apa. Dari keduanya itu dan pihak-pihak yang terkait, perlu bersama-sama saling terbuka dan membuat pembelajaran yang menyenangkan agar suatu pembelajaran itu nanti menjadi hal yang tidak menakutkan dan pada akhirnya enjoy untuk menjalani tanpa adanya rasa tekanan yang kemudian hal itu cukup berpengaruh terhadap kondisi mental individu atau peserta didik supaya lebih bersemangat dan menjadi lebih termotivasi. Menanamkan mindset yang positif dalam pikiran juga cukup berpengaruh besar terhadap kondisi mereka nantinya.

\section{UCAPAN TERIMA KASIH}

Selesainya artikel karya ilmiah ini, penulis ucapkan terimakasih kepada Allah SWT karena telah memberikan rahmat-Nya sehingga penulis dapat menyelesaikan artikel karya ilmiah ini tepat waktu, dan juga kepada Bapak Dr. Pujiriyanto S.Pd, M.Pd selaku dosen mata kuliah Penulisan Karya Ilmiah yang telah membimbing dan mengarahkan jalannya penelitian ini. Selain itu penulis juga mengucapkan terimakasih kepada pihak yang telah membantu dan mendukung penelitian artikel ini.

\section{DAFTAR PUSTAKA}

Efendi, R. (2020). Hubungan Sistem Pembelajaran Daring dengan Kesehatan Mental Mahasiswa Di Era COVID-19 Menggunakan Chi-Square Test dan Dependency Degree. Seminar Nasional Teknologi Informasi ..., 600-607. http://ejournal.uinsuska.ac.id/index.php/SNTIKI/article/vie w/11197

Perencanaan, K., Nasional, P., Republik, B., Abstraksi, I., Baru, N., Pembangunan, R., Menengah, J., Kunci, K., Journal, T. I., Planning, D., \& Iv, V. (2020). Covid-19, New Normal, dan Perencanaan Pembangunan di Indonesia. Jurnal Perencanaan Pembangunan: The Indonesian Journal of Development Planning, 4(2), 240-252. https://doi.org/10.36574/jpp.v4i2.118

Ardhani, A. D., \& Syalsabhila, A. (2020). 
Realita dan Harapan: Wajah Pendidikan Tinggi Indonesia di Tengah Pandemi. Kacamata Driyarkara, September, 1-15.

Badaruddin, A., Erlamsyah, E., \& Said, A. (2016). Hubungan Kesehatan Mental dengan Motivasi Belajar Siswa. Konselor, $5(1), \quad 50$. https://doi.org/10.24036/02016516543-000

Basar, A. M. (2021). Problematika Pembelajaran Jarak Jauh Pada Masa Pandemi Covid-19. Edunesia: Jurnal Ilmiah Pendidikan, 2(1), 208-218. https://doi.org/10.51276/edu.v2i1.112

Browning, M. H. E. M., Larson, L. R., Sharaievska, I., Rigolon, A., McAnirlin, O., Mullenbach, L., Cloutier, S., Vu, T. M., Thomsen, J., Reigner, N., Metcalf, E. C., D’Antonio, A., Helbich, M., Bratman, G. N., \& Alvarez, H. O. (2021). Psychological impacts from COVID-19 among university students: Risk factors across seven states in the United States. PloS One, 16(1), e0245327. https://doi.org/10.1371/journal.pone.0245 327

Christianto, L. P., Kristiani, R., Franztius, D. N., Santoso, S. D., Winsen, \& Ardani, A. (2021). Kecemasan Mahasiswa Di Masa Pandemi Covid-19. Jurnal Selaras: Kajian Bimbingan Dan Konseling Serta Psikologi Pendidikan, 3(1), 67-82. https://doi.org/10.33541/jsvol2iss1pp1

Deliviana, E., Maria Helena Erni, Putri Melina Hilery, \& Novi Melly Naomi. (2021). Pengelolaan Kesehatan Mental Mahasiswa Bagi Optimalisasi Pembelajaran Online Di Masa Pandemi Covid-19. Jurnal Selaras: Kajian Bimbingan Dan Konseling Serta Psikologi Pendidikan, 3(2), 129-138.

Fitriyani, Y., Fauzi, I., \& Sari, M. Z. (2020). Motivasi Belajar Mahasiswa Pada Pembelajaran Daring Selama Pandemik Covid-19. Profesi Pendidikan Dasar, 7(1), 121-132. https://doi.org/10.23917/ppd.v7i1.10973

Hadi, I., Wijayanti, F., Devianti, R., \& Rosyanti, L. (2017). Gangguan Depresi Mayor (Mayor Depressive Disorder) Mini Review. Health Information: Jurnal Penelitian, 9(1), 25-40. https://doi.org/10.36990/hijp.v9i1.102

Hardani, Auliya, N. H., Andriani, H., Ustiawaty, R. A. F. J., Utami, E. F., Sukmana, D. J., \& Ria Rahmatul Istiqomah. (2015). Buku Metode Penelitian Kualitatif dan Kuantitatif. In
Pustaka Ilmu (Issue March).

Hasfira, H., \& Marelda, M. (2021). Peran Guru Dalam memotivasi Siswa Pada Masa Pandemi. Jurnal Pendidikan Dan Konseling (JPDK), 3(1), 80-84. https://doi.org/10.31004/jpdk.v3i1.1430

Indasari, S. R., Wijaya, A. W. A. W., Layuk, M., Sambo, M. S., \& Indrawati, M. (2020). Buku Saku Dukungan Psikososial Bagi Guru \& Siswa Tangguh di Masa Pandemi Covid-19. Wahana Visi Indonesia, 1-26. https://wahanavisi.org/userfiles/post/201 0055F7AA525E16B6_LGID.pdf

Journal, L. (2017). Lantanida Journal,. 5(2).

Lestari, B. M., \& Magdalena, I. (2021). Dampak Mental Bagi Siswa Sdn Buaran Mangga Ii Akibat Pembelajaran Jarak Jauh. 1(2), 121-129.

Lindasari, S. W., Nuryani, R., \& Sukaesih, N. S. (2021). Dampak Pembelajaran Jarak Jauh Terhadap Psikologis Siswa Pada Masa Pandemik Covid 19. Jnc, 4(2), 130-137.

Moh Muslim. (2020). Moh . Muslim : Manajemen Stress pada Masa Pandemi Covid-19 " 193. Jurnal Manajemen Bisnis, 23(2), 192-201.

Nugraheny, A. R. (2020). Peran teknologi, guru dan orang tua dalam pembelajaran daring di masa pandemi. Peran Teknologi, Guru Dan Orang Tua Dalam Pembelajaran Daring Di Masa Pandemi, 7.

Perencanaan, K., Nasional, P., Republik, B., Abstraksi, I., Baru, N., Pembangunan, R., Menengah, J., Kunci, K., Journal, T. I., Planning, D., \& Iv, V. (2020). Covid-19, New Normal, dan Perencanaan Pembangunan di Indonesia. Jurnal Perencanaan Pembangunan: The Indonesian Journal of Development Planning, 4(2), 240-252. https://doi.org/10.36574/jpp.v4i2.118

Putri, K., \& Sugiasih, I. (2020). Hubungan antara Regulasi Emosi dan Kontrol Diri ( Self- Control ) dengan Perilaku Menyimpang pada Siswa di SMA “ $X$.” 2(November), 53-62.

Setyawan, I. (2020). Peran Orang Tua Dalam Pendampingan Belajar Daring. Cetta: Jurnal Ilmu Pendidikan, 3(3u SEArticles).

https://jayapanguspress.penerbit.org/inde x.php/cetta/article/view/955

Sidig, D. S. (2015). Rmk metode penelitian pertemuan vii.

Suardana, A. A. P. C. P., \& Simarmata, N. 
(2013). Hubungan Motivasi Belajar dan Kecemasan Menjelang Ujian. Jurnal Psikologi Udayana, 1(1), 203-212.

Wijaya, C. (2021). Covid-19: "Stres, mudah marah, hingga dugaan bunuh diri", persoalan mental murid selama sekolah dari rumah. Www.Bbc.Com. https://www.bbc.com/indonesia/indonesi a-55992502

Zed, M. (2014). Metode Penelitian Kepustakaan. Jakarta: Yayasan Obor Indonesia. 